\title{
東南アジア関係文献目録 (1994年11月～1995年10月）
}

この文献目録は，1994年11月から1995年10月までの間に日本国内で発行された書籍 および学術誌掲載論文のうち, 自然科学系を除いた, 東南アジアに関係の深いものを 採録したものである。本文献目録の東南アジアには, ブルネイ, ビルマ, カンボジア, インドネシア, フィリピン, ラオス, マレーシア, シンガポール, タイ, ベトナムの 10 力国のほか, 雲南・広西, 一部太平洋地域が含まれる。

昨年度同様, 全体を「書籍の部」と「論文の部」に分け，その中では国別に分類し， 著者はすべて著者・編者名の50音順に並べた。複数の国にまたがる内容のものについ ては，「書籍の部」・「論文の部」ともに「一般」の項目に分類した。

採録基準も昨年度どおり，以下のようにさせていただいた。

(1) 書籍については, 従来どおり戦記, 旅行ガイドブックの類（旅行会話集を含 む)，および経済投資動向・日系企業の動向などを主内容とするものは割愛し た。

(2)論文については, 従来どおり原則として論文形式に従ったもので, 10頁以上の ものを採録した。

なお,これらに際してはより確実な入手の便宜を考えて, 関係出版社, 書店, 図書 館において, 書籍, 論文ともに現物の確認を必ず行っている。

文献目録作成に当たっては，会員の多谷 鋭，小座野八光の各氏，また採録作業に は中野裕子をはじめとする東京外国語大学東南アジア語学科の学生たちの協力を得た。 この場を借りて厚くお礼申しあげる。

(石井和子) 
東南アジア 一歷史と文化一 №.25, 1996

\section{一薈籍の部——}

凡例：著者, 編者名のあとは, (1)本のタイトル, (2)出版社, (3)定価(円), (4)頁数, (5) 発行年月の順になっています。

\section{〈一 般〉}

赤木 攻 (1)1940年代アジア総合年表 (2)大阪外国語大学アジア研究会 (3)非売品 (4) 310 (5) 1995.3

明石陽至, 石井均解題 (1)大東亜建設審議会関係史料(全 4 巻) (2)龍溪書舎 (3) 82,400 (4) 1,710 (5) 1995.7

アジア経済研究所編 (1)冷戦後の東南アジアにおける信頼䤑成と重層的地域協力 一一国際シンポジウム報告書 (2)アジア経済研究所 (3)非売品 (4)263 (5) 1995.3

アジア・ネットワーク編 (1)インドシナ情報事典 (2)急み文社発行, 星雲社発売 (3) 1,750 (4) 432 (5) 1995.1

安藤勝美編著 (1)地域協力機構と法——アジア・ラテンアメリカ地域主義の現代的意

義（2)アジア経済出版会 (3)3,200 (4)246 (5) 1994.12

伊東照司 (1)インド東南アジア古寺巡礼 (2)雄山閣出版 (3) 2,884 (4)178 (5)1995. 8

井村哲朗編 (1)米国議会図書館蔵 戦前期アジア関係日本語逐次刊行物目録 (2)アジ ア経済出版会 (3)7,500 (4)501 (5) 1995.3

岩武照彦 (1)南方軍政下の経済施策——ライ・スマトラ・ジャワの記録 (全 2 巻)

(2)龍溪書舎 (3) 30,900 (4)780 (5) 1995.5

大野幸一, 岡本由美子編著 (1) EC, NAFTA, 東アジアと外国直接投資——発展途

上国への影響（2)アジア経済出版会（3)5,900 (4)494 (5)1995. 3

小川雄平編著 (1)夕イの工業化と社会の変容——日系企業は夕イをどう変えたか(ア

ジア太平洋センター研究叢書 1) $\quad$ (2)九州大学出版会 (3) 2,884 (4) 151

(5) 1995.7

関西学院大学東洋史学研究室編 (1)アジアの文化と社会 (2)法律文化社 (3)9,785

(4) 380 (5) 1995.6

近代アジア教育史研究会編 (1)近代日本のアジア教育認識(目録編) (2)龍溪書舎

\section{9,270 (4) 203 (5) 1995.7}

蔵前仁一+「旅行人」編集室 （1)メコンの国旅行情報ノート （2)凱風社 （39980 (4) 126 (5) 1995.4

後藤乾一 (1)近代日本と東南アジア——南進の「衝撃」と「遺産」 (2)岩波書店 (3) 3,600 (4) 345 (5) 1995.1

坂本義和編 (1)世界政治の構造変動 第 3 巻——発展 (2)岩波書店 (3) 3,400 (4) 306 (5) 1994.12 
瀬戸正夫 (1)父と日本にすてられて——その半生を通した東南アジアの歴史 (2)か のう書房 (3) 3,500 (4) 475 (5) 1995.10

高崎直道，木村清孝編著 (1)東アジア仏教とは何か (2)春秋社 (3)3,605 (4)316 (5) 1995. 4

田中耕司, 小泉格 (1)講座 文明と環境 第10巻一一海と文明 (2)朝倉書店 (3) $3,800 \quad$ (4) $218 \quad$ (5) 1995.10

日本大学農獣医学部国際地域研究所編 (1)東南アジアの食品加工業 (2)龍溪書舎 (3) 2,300 (4)173 (5) 1995.2

野村亨他著 (1)東南アジア世界の実像 一 国家形成の歴史と経済発展 (2)中央経済 $\begin{array}{llll}\text { 社 (3) } 1,900 & \text { (4) } 232 \quad \text { (5) } 1995.12\end{array}$

萩原宣行, 後藤乾一編著 (1)東南アジアのなかの近代日本 (2)みすず書房 (3)2,884 (4) $272 \quad$ (5) 1995.7

野村 亨 (1)民族・宗教・国家 (2)慶応通信社 (3) 1,200 (4)265 (5) 1995.8 㱜田康行編著 (1)「南方共栄圏」一一戦時日本の東南アジア経済支配 (2)多賀出版 (3) 10,094 (4) 857 (5) 1995.2

福井隆, 小林紀晴, 関口佐千夫 (1)ベトナム・センチメンタル+ラオス・カンボジア (2)情報センター出版局 (3)1,600 (4)200 (5)1995

福家洋介編著 (1)東南アジアってどこ? ——近くて遠い国アジアを考える本 2 岩崎書店 (3)2,800 (4)70 (5)1995.4

福家洋介編著 (1)かわりゆく農村のくらし——近くて遠い国アジアを考える本 4 $\begin{array}{llll}\text { (2)岩崎書店 (3) } 2,800 & \text { (4)70 (5) } 1995.4\end{array}$

水野広祐 (1)東南アジア農村の就業構造（2)アジア経済出版会 (3)3,100 (4)254 (5) 1995. 3

村井吉敬編著 (1)アジアとどうつきあうか一一近くて遠い国アジアを考える本 7 (2)岩崎書店 (3)2,800 (4)66 (5)1995.4

吉沢四朗, 高柳先男編著 (1)日本 ODA の総合的研究—夕イにおける事例 (中央大 学企業研究所研究叢書 9) (2)中央大学出版部 (3) 3,399 (4)315 (5) 1995 . 3

林華生著 (1)日本・ASEAN 共存の構図（中川多喜雄, 吉村雄策訳） (2)文眞堂 (3) 2,678 (4) 158 (5) 1995.3

和田幸子 (1)東南アジア経済社会論 一山と川と海の結び合う世界 (2)創元社 (3) 2,500 (4) 254 (5) 1995.7

米倉 等 （1)不完全市場下のアジア （2)アジア経済出版会 （3)2,400 (4)194 (5)1995. 3

\section{〈ブルネイ〉}

野村亨訳編 (1)ブルネイの古代史 (2)日本ブルネイ友好協会 (3)非売品 (4)137 (5) 
東南アジア 一歴史と文化一 №.25, 1996

1995.6

\section{〈ビルマ〉}

綾部恒雄, 石井米雄編 (1)もっと知りたいミャンマー (2)弘文堂 (3)2,300 (4)289 (5)1995.12

生野善応 (1)ビルマ仏教——その実態と修業 (2)大蔵出版 (3) 3,500 (4)318 (5) 1995.10

池田正隆 （1)ビルマ仏教——その歷史と儀礼・進行 (2)法蔵館 (3)2,500 (4)227 (5) 1995.8

岩永友宏 (1)戦うカレン族—ビーマ辺境訪問記（2)凱風社 (3)1,339 (4)150 (5) 1995. 2

加藤敬, ドゥ・キン・イー (1)ミャンマー憧景——祈り篤き人々の素顔（アジア民俗

$\begin{array}{llll}\text { 写真叢書14） } & \text { (2)平河出版社 (3)3,811 } & \text { (4)199 } & \text { (5)1995.7 }\end{array}$

じっこくおさむ (1)ミャンマー物語—人はなぜ戦争をするのか (2)三省堂 (3) 2,500 (4) 342 (5) 1995.3

バー・モウ (1)ビルマの夜明け——バー・モウ (元国家元首)独立運動回想録 新版(横 $\begin{array}{llll}\text { 堀洋一訳） (2)太陽出版 (3) } 3,605 & \text { (4) } 449 & \text { (5) } 1995.7\end{array}$

三上義一 (1)アウン・サン・スーチー囚われの孔雀 (2)講談社 (3)680 (4)406 (5) 1995. 7

南田みどり編訳 (1)ミャンマー現代短編集 1 (2)大同生命国際文化基金 (3)1,300 (4) 243 (5) 1995.2

南田みどり他著 (1)激動の文学 (2)信濃毎日新聞社 (3)3,000 (4)279 (5)1995.3

吉川利治 (1)泰緬鉄道 機密文書が明かすアジア太平洋戦争 (2)同文館 (3)3,900 (4) 352 (5) 1994.11

吉田敏浩 (1)森の回廊——ビルマ辺境, 民族解放区の1300日 (2)日本放送出版協会 (3) 2,500 (4) 494 (5) 1995.9

エドモンド・R・リーチ（1)高地ビルマの政治体系（関本照夫訳） (2)弘文堂 (3)5,974 (4) $388 \quad$ (5) 1995.3

\section{〈カンボジア〉}

石澤良昭編著 (1)カンボジア文化の復興 第11号 (2)上智大学アジア文化研究所 (3) 非売品 (4) 350 (5) 1995.5

黒蓮伊惣朗。(1)ポルポト最後の秘密——カンボジアPKOの裏表 (2)彩流社 (3) 2,000 (4) 216 (5)1995. 4

近藤順夫 (1)カンボジアPKO ゆれ動いた372日（2)日本評論社 (3)1,648 (4)248 (5) 1994

自由人権協会 (1)カンボジアの刑務所の問題点とその改革の方向現地調査報告 (2)自 
由人権協会 (3)1,030 (4)51 (5)1995.3

ブリュノ・ダジャンス著, 石澤良昭監修 (1)アンコールワット——密林に消えた文明 を求めて (2)創元社 (3) 1,400 (4) 214 (5) 1995.6

デービット・P・チャンドラー（1)ポルポト伝（山田實訳）（2)めこん（3)2,575

361 (5) 1994.11

$\mathrm{P} ・$ デービス著, N・ダンロップ撮影 (1)地雷に浮かぶ国カンボジア (Asahi news shop

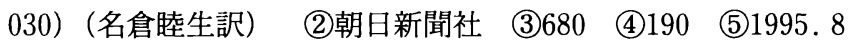

日本国政府アンコール遺跡救済チーム編 (1)アンコール遺跡調査報告書1995 (2)財団

法人日本国際協力センター (3)非売品 (4)41,126 (5)1995.7

日本国政府アンコール遺跡救済チーム編 (1) Preliminary Report on the Technical

Survey of Angkor Monument(1) (2)日本国政府アンコール遺跡救済チー

厶 (3)非売品 (4)420 (5) 1994.12

フーオッタット (1)アンコール遺跡とカンボジアの歷史（今川幸雄編訳） (2)めこん $\begin{array}{llll}(3) 2,060 & \text { (4) } 135 & \text { (5) } 1995.7\end{array}$

三好範英 (1)カンボジアPKO 地域紛争解決と国連 (2)亜紀書房 (3)1,900 (4)326 (5)1994.11

〈インドネシア〉

綾部恒雄, 石井米雄編 (1)もっと知りたいインドネシア 第2 版 (2)弘文堂 (3)2,300 (4) 289 (5) 1995.3

$\begin{array}{lllll}\text { 磯松浩滋 (1)どこへ行くインドネシア } & \text { (2)めこん } & \text { (3)2,060 } & \text { (4)197 } & \text { (5)1995. } 3\end{array}$ インドネシア共和国教育文化省文化庁編 (1)インドネシア造形美術史——インドネ シア文化入門（亀井はるみ，塩見真知子訳）（2)サンガル・スニ・ルパ (3) 2,575 (4) $318 \quad$ (5) 1995.9

岡崎 務 (1)世界各地のくらし 4 インドネシアのくらし——日本の子供たちがみ た世界最大の島国インドネシア (2)ポプラ社 $\quad$ (3) 2,400 (4) 47 (5) 1995.4 小黒啓一, 小浜裕久 (1)インドネシア経済入門——構造調整と輸入発展 (2)日本評論 社 (3) 2,678 (4) 183 (5) 1995.5

カルメル・ブディアルジョ，リム・スイ・リオン (1)インドネシアの先住民族と人権 問題 一一西パプアにみる民族絶滅政策（小野寺和彦訳） (2)明石書店 (3) 4,100 (4) 348 (5) 1995.2

倉沢愛子 (1)二十年目のインドネシア——本とアジアの関係を考える (2)草思社 (3) 1,900 (4) $277 \quad$ (5) 1994.11

倉沢愛子解題 (1)農村実態調査——ジョクジャ州・ボゴール州・マラン州 (2)龍溪書 $\begin{array}{llll}\text { 舎 (3) } 27,810 & \text { (4) } 500 \quad \text { (5) } 1995.4\end{array}$

小松邦康 (1)インドネシア全二十七州の旅（2)めこん $\quad$ (3)1,957 (4)295 (5) 1995. 
鈴木正夫 (1)スマトラの郁達夫一一太平洋戦争と中国作家 (2)東方書店 (3) 1,900 (4) 307 (5) 1995.6

エディ・ヘルマワン (1)インドネシア華人の歩み (2)創栄出版 (3)4,000 (4)374 (5) 1995. 3

MASSARDI, ANM YUDHISTIRA (1)アルジュナドロップアウト（押川典昭訳） $\begin{array}{lllll}\text { (2)めこん (3) } 1,854 & \text { (4) } 225 \text { (5) } 1995.7\end{array}$

$\begin{array}{llllll}\text { 増田 妙 } & \text { (1)おいしいBALI } & \text { (2)めこん } & \text { (3) } 1,854 & \text { (4)105 } & \text { (5)1995. } 1\end{array}$

安間繁樹 （1)カリマンタンの動物たち（2)日経サイエンス 2

山田道隆 (1)いまインドネシアがおもしろい——外信記者が見た多様性国家 (2)勁 草書房 (3) 2,884 (4) 315 (5) 1995.4

\section{〈ラオ ス〉}

青山利勝 (1)ラオス インドシナ緩衝国家の肖像 (2)中央公論社 (3)740 (4)236 (5) 1995.5

塚田大願 （1)ラオスの回想記（2)光陽出版社（3)1,500 (4)181 (5)1995.4

根岸範子，前田初江（1)ラオスの民話（2)黑潮社（31,600 $\quad$ (4)254 (5)1994.12

〈マレーシア〉

綾部恒雄, 石井米雄編 (1)もっと知りたいマレーシア 第2 版 (2)弘文堂 (3)2,300 (4) 293 (5) 1994.12

$\begin{array}{lllll}\mathrm{A} ・ \mathrm{D} ・ ウ ォ レ ス & \text { (1)新装版 マレー半島（宮田杉訳） (2)新思索社 (3)6,800 (4)685 }\end{array}$ (5)1995. 8

小木裕文 (1)シンガポール・マレーシアの華人社会と教育変容 (2)光生館 (3)4,120 (4)199 (5) 1995.2

竹内 洋 (1)マレーシアの投資関連税制便覧 （2)アジア経済出版会 （3)1,600 (4)128 (5) 1994.11

根津 清 (1)マハティール—ーアジアの世紀を創る男 (2)ザ・マサダ (3)1,500 (4) 228 (5)1994.11

原不二夫編訳（1)マレーシア抗日文学選（東南アジアブックス115） (2)勁草書房 (3) 2,575 (4) 282 (5) 1994.12

原不二夫 (1)ブミプトラ企業の抬頭とマレー華人経済協力（ASEAN 等現地研究シリ

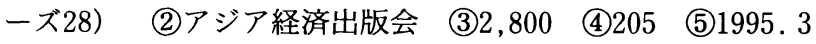

若竹七海, 加門七海, 高野宣季 (1)マレー半島すちゃらか紀行 (2)新潮社 (3)1,500 (4) $266 \quad$ (5) 1995.7 


\section{〈フィリピン〉}

麻生洋央 (1)まほろしの珈琲——サリサリコーヒー・ハロハロライフ (2)末来文化社 発行, 里文出版発売 (3) 1,800 (4) 229 (5)1995. 6

綾部恒雄, 石井米雄編 (1)もつと知りたいフィリピン第 2 版 (2)弘文堂 (3)2,300 (4) 277 (5) 1995.2

家田荘子 (1)恋したはずのフィリピーナ（2)角川書店（3) 1,000 (4)192 (5)1995.7 石田甚太郎 (1)マンゴーの花咲く戦場 (2)新読書社 (3) 2,000 (4) 393 (5) 1995.6 内山安雄 (1)マニラ・パラダイス (2)集英社 (3) 1,700 (4) 358 (5) 1995.4 黒木純一朗 (1)日本人の落とし子たち一一恋の行方は誰の責任か (2)クレスト社 (3) 1,500 (4) 263 (5) 1995.11

榊原芳雄 (1)フィリピン経済入門——建るか ASEAN のトップランナー (2)日本評 論社 (3) 2,678 (4) 162 (5) 1994

山崎克彦 (1)何もなくて豊かな島——南海の孤島カオハガンに暮らす (2)新潮社 (3) 1,250 (4) $211 \quad$ (5) 1995.6

シンシア・D・ノラスコ (1)フィリピン都市下層社会 (2)明石書店 (3)2,000 (4) 156 (5) 1994.12

鷹沢のり子 (1)バターン「死の行進」を歩く (2)筑摩書房 (3) 1,800 (4)197 (5)1995. 7

生江有二 (1)山下財宝—フィリピン黄金伝説を行く（2)文藝春秋 (3)2,000 (4) 334 (5) 1995.10

南條岳彦 (1)一九四五年 マニラ新聞——ある毎日新聞記者の終章 (2)草思社 (3) 2,200 (4) 269 (5)1995. 2

浜なつ子 (1)おおらかで, 優しくて, いいかげんな神様からの贈り物——フィリピン 路地裏の日比混血児 (2)風樹社発行, どうぶつ社発行 (3) 2,200 (4) 226 (5)1995. 7

松永 努 (1)マニラ不思議物語 (2)論創社 (3) 2,060 (4) 283 (5) 1995.8 マリア・ロザリオ・ピケロ・バレスカス (1)真の農地改革をめざして——フィリピン （国際社会叢書 アジア編 2 ) (角谷多佳子訳) (2)国際書院 (3)3,200 (4) 195 (5) 1995.5

森 俊二 (1)わたしは犯罪者 (2)宝島社 (3)1,100 (4)229 (5)1995.3 ウラル・V・ファベリア, 坂井英吉編 (1)フィリピンの国内資源動員とその利用— フィリピン日本共同研究（ASEAN 等現地研究シリーズ No.26） (2)アジ ア経済出版会 (3)3,100 (4)231 (5) 1995.3

歴史教育者協議会編集 (1)知っておきたいフィリピンと太平洋の国々 (2)青木書店 $\begin{array}{llll}\text { (3) } 2,884 & \text { (4) } 242 & \text { (5) } 1995.1\end{array}$ 龍溪書舎編集部編 (1)明治後期産業発達史資料 第246巻 (外国事情篇 3 ) 清国窯業調 查報告書・比津浜群島事情（2)龍溪書舎 (3)22,660 (4)144,278 (5)1995. 
野田一郎指導, 岡崎務文・写真 (1)世界各地のくらし 6 フィリピンのくらし—— 本の子供たちがみた,多国籍国家フィリピン (2)ポプラ社 (3) 2,400 (4) 47 (5) 1995.4

\section{〈シンガポール〉}

アラン・エリオット (1)シンガポールのシャーマニズム (佐々木宏幹監修, 安田ひろ
み，杉井純一訳）
(2)春秋社 (3)3,914
(4) 256
(5) 1995.10

佐々木譲 （1)昭南島に蘭ありや（2)中央公論社 (3)2,000 (4)477 (5)1995.8

竹下秀邦 (1)シンガポール—リー・クアンュウの時代 (2)アジア経済出版会 (3) 4,800 (4)596 (5)1995. 4

陳儀文（勢子）（1)ミセス陳と呼ばれて一一華僑になった日本人（2)文藝春秋（3) 1,500 (4) 221 (5) 1995.3

リム・チョンヤー編著 (1)シンガポールの経済政策（上）（岩崎輝行，森健訳） (2)勁 草書房 (3) 4,120 (4) 383 (5) 1995.4

リム・チョンヤー編著 (1)シンガポールの経済政策（下）（岩崎輝行，森健訳） (2)勁

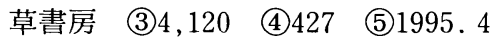

\section{〈夕 イ〉}

$\begin{array}{lllll}\text { 赤木 攻 (1)アジア読本タイ } & \text { (2)河出書房新社 (3)2,000 } & \text { (4)329 } & \text { (5)1994.8 }\end{array}$

綾部恒雄，石井米雄編著 (1)もつと知りたい夕イ 第2 版 (2)弘文堂 (3)2,300 (4) 301 (5)1995. 3

五十嵐勉, 岩城雄次朗編著 (1)微笑の国夕イ (2)アジア文化社発行, 星雲社発売 (3) $2,800 \quad$ (4) 313 (5) 1995.8

$\begin{array}{llllll}\text { 石井米雄 (1)メコン (2)めこん } & \text { (3)2,884 } & \text { (4)192 } & \text { (5)1995.9 }\end{array}$

稲垣三千穂 (1)夕イ・ギンペット物語——スラムからみた微笑の国 (2)明石書店 (3) $\begin{array}{lllll}1,648 \quad(4) 217 & \text { (5) } 1995.8\end{array}$

小川雄平編著 (1)夕イの工業化と社会の変容——日系企業は夕イをどう変えたか

$\begin{array}{lllll}\text { (2)九州大学出版会 (3)2,884 } & \text { (4)151 } & \text { (5) } 1995.7\end{array}$

加藤和英 (1)夕イ現代政治史 (2)弘文堂 (3)6,000 (4)396 (5) 1995.10

河部利夫 (1)歴史の転換を生きてこの50年 (2)玉川学園大学出版部 (3)2,884 (4) 238 (5)1995. 1

北原淳，赤木攻編著 (1)夕イ工業化と地域社会の変動 (2)法律文化社 (3)9,785 (4) 454 (5) 1995.4

久保田義善, 北出俊昭編著 (1)協同組合と農民組織—タイ・インド・日本 (2)筑波 書房 (3) 6,000 (4) 449 (5) 1995.1

佐藤 宏 (1)夕イのインド人社会——東南アジアとインドの出会い(アジアを見る目 
92）（2)アジア経済出版会 (3) 1,400 (4)259 (5)1995. 3

プラパン・サヴェタナン，林俊昭編（1)2000年に向けてのタイ経済——タイ日本共同

研究（ASEAN 等現地研究シリーズNo.25） (2)アジア経済出版会 (3) 2,100 (4) 157 (5) 1995.3

ティップワーニ・サンケットゥオン (1)祖母さんの木の遺産——素晴らしきタイの

暮らし（アジアからの贈りもの）（中村美津子訳） (2)段々社発行，星雲社

発売 (3) 1,500 (4) 172 (5) 1995.10

下館事件タイ三女性を考える会編 (1)売春社会日本へ——イ女性からの手紙

明石書店 (3) 1,600 (4)219 (5)1995.5

新小岩事件を考える会編 (1)新小岩事件報告集——裁かれるべきは夕イの女性たち

ではない（2)新小岩事件を考える会 (3)700 (4)80

杉下恒夫 (1)ジャーナリストが歩いて見た ODA——タイ縦断800キロの現場レポー

$\begin{array}{lllll}\text { 卜 (2)国際開発ジャーナル } & \text { (3)2,000 } & \text { (4) } 221 & \text { (5) } 1995.3\end{array}$

SUMIT・HEMASATHOL (1)農村医療と開発にかけたドクターカセーの半生（坂田 久美子編訳）（2)大同生命国際文化基金 (3)1,300 (4)212 (5)1995.3

園部益子編 (1)日タイ関係文献目録１978～1992年（2)アジア経済出版会（3)2,500 (4) $181 \quad$ (5) 1995.3

高梨和紘編著 (1)夕イ経済の変容と政策課題 (2)文真堂 (3)3,708 (4)235 (5)1995.10 田坂敏雄 (1)熱帯林破壊と筫困化の経済学—夕イ資本主義化の地域問題 (2)御茶 の水書房 (3) 3,605 (4)279 (5)1994.12

新澤正禎 (1)夕イの職業教育——統計資料で見る (2)アジア経済出版会 (3)3,800 (4) 466 (5) 1995.10

プラサート・ヤムクンフング (1)発達の岐路に立つタイ（国際社会学叢書アジア編 5) $\begin{array}{lllll}\text { （松薗裕子，鈴木規之訳）（2)国際書院 (3)3,200 } & \text { (4)229 (5)1995. } 3\end{array}$ プラパン・サヴェタナン，林俊昭編著 (1)2000年に向けてのタイ経済 (ASEAN 等現 地研究シリーズ25）（2アジア経済出版会（3)2,100 (4)157 (5)1995.3 益本仁雄 (1)市場経済化・情報化にゆれるアンカイ村一一北夕イの未電化村 (2)近代 $\begin{array}{lllll}\text { 文芸社 (3)2,900 (4)191 } & \text { (5)1995.3 }\end{array}$

松下正弘編, タイ文化研究会著 (1)タイ文化ハンドブック—道標微笑の国へ (2)勁 $\begin{array}{llll}\text { 草書房 (3) } 2,575 & \text { (4)298 } & \text { (5) } 1995.3\end{array}$

\section{〈ベトナム〉}

穴吹 充 (1)ベトナム人と日本人 (2) PHP 研究所 (3)1,300 (4)236 (5)1995.2 岡村昭彦の会編 (1)シャッター以前 2 — 岡村昭彦研究 (2)川島書店発売 (3) 1,800 (4)116 (5) 1995.3

臣永正廣文，外山ひとみ写真 (1)ヴェトナム・ディープ・ウォッチ (2)徳間書店 (3) 720 (4) 190 (5) 1995.6 
臣永正廣文, 外山ひとみ写真 (1)ヴェトナムドリーム——女たちが支える, いま注目 の国 (2)朝日ソノラマ (3) 1,300 (4) 212 (5) 1995.4

加藤 長 (1)青春のハノイ放送 (2)共栄書房発行, 花伝社発売 (3)1,500 (4)227 (5) 1995. 8

河野 實 (1)誰も書かなかった素顔のベトナム——越南4000キロ訪問記 (2)同友館 $\begin{array}{llll}(3) 1,600 & \text { (4) } 243 & \text { (4) } 1995.2\end{array}$

松本三朗，川本邦衛編著 (1)べトナムと北朝鮮，岐路に立つ二つの国 (2)大修館 (3) 3,090 (4) 454 (5) 1995.4

神田憲行 (1)ヴェトナムへ行こう!! (朝日ワンテーママガジン46) (2)朝日新聞社 (3) 1,300 (4) 218 (5) 1995.3

グェン・スアン・オアイン (1)概説ベトナム経済——アジアの新しい投資フロンティ

$\begin{array}{lllll}\text { ア（丹野勲編訳）（2)有斐閣 (3) } 1,854 & \text { (4) } 272.5 & \text { (5) } 1995.10\end{array}$

玉島文雄, 竹内郁雄編著 (1)社会主義ベトナムとドイモイ（研究双書 No.446） (2)ア

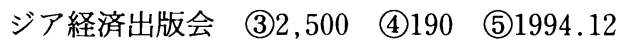

桜井由躬雄編著 (1)もっと知りたいべトナム（第 2版） (2)弘文堂 (3)2,300 (4)293 (5) 1995.8

佐藤経明他著 (1)変貌するアジアの社会主義国家一一中国・ベトナム・朝鮮（日本国

$\begin{array}{lllll}\text { 際フォーラム叢書）（2)三田出版会 (3) } 1,800 & \text { (4)264 } & \text { (5) } 1995.6\end{array}$

潤田順一（1)勃興のベトナム——ジアを変えるドイモイ経済（2)中央経済社（3) 2,200 (4) 278 (5) 1995.10

ティックナットハン (1)微笑を生きる〈気づき〉の瞑想と実践 (2)春秋社（池田久代 $\begin{array}{llll}\text { 訳) (3) } 1,957 & \text { (4) } 201 & \text { (5) } 1995.4\end{array}$

中原光信 (1)ベトナムへの道一一日越貿易の歴史と展望 (2)社会思想社 (3)3,000 (4) 336.31 (5) 1995.7

クリストフ・バタイユ（1)安南——愛の王国（辻邦生訳） (2)集英社 (3) 1,400 (4) 142 (5) 1995.5

ファム・カク・ホエ (1)ベトナムのラストエンペラー（20世紀のメモリアル）（白井昌 也訳） (2)平凡社 (3) 3,200 (4)473 (5)1995. 1

古田元夫 (1)べトナムの世界史一一華世界から東南アジア世界へ (2)東京大学出 版会 (3) 2,678 (4) 274.4 (5) 1995.9

古森義久 (1)ヴェトナムの記憶——戦争と革命そして人間 (2) PHP 研究所 (3) 1,500 (4) 227 (5) 1995.8

辺見 庸 (1)八ノイ挽歌 （2)文藝春秋 (3)480 (4)267 (5) 1995.10

本多勝一 (1)本多勝一集（第11集・北爆の下） (2)朝日新聞社 (3) 3,900 (4)492 (5) 1995. 2

メアリー・M・ロジャーズ（1)べトナム（目で見る世界の国々27）（青山保訳） (2)国 土社 (3) 2,600 (4) 67 (5) 1995.3 


\section{一論文の部}

凡例：著者名のあとは，(1)論文のタイトル，(2)掲載書名（出版社）・雑誌名（号数）, (3)頁数, (4)発行年月の順になっています。

\section{$\langle$ 一 般〉}

青柳洋治 (1)陶片が語る海上交易のネットワーク——南シナ海海域の陶磁貿易の変 遷（2)講座文明と環境：10一海と文明(朝倉書店) (3)86〜108 (4) 1995.10 市川健二郎 (1)第十三回国際アジア歷史者会議について $\quad$ (2)東方学90 (3)137〜144 (4) 1995.7

市川健二郎 (1)東南アジア華僑の土着化と民族性 (2)アジアの民族造形一一金子量 重先生古希記念文集（徵蔵館） (3) 1 ～10 (4)1995.11

市川信愛 (1)華僑ネットワーク研究の視座 (2)九州国際大学国際商学部紀要 5 周年記 念特集号 (3)145〜166，409〜411 (4) 1995.5

市川信愛 (1)近代在日華商の中国海域交易圏の変容に関する実証的研究 (2)学術月報 48(8) (3) $822 \sim 829$ (4) 1995.8

池端雪浦 (1)第13回国際アジア歴史家会議から——ロキアム：東南アジアにおけ る東南アジア史研究（2)東南アジア：歴史と文化24 (3)126〜135 (4) 1995 . 6

井上 甫 (1)アジア地域における日本企業の技術移転と人材育成——シガポー

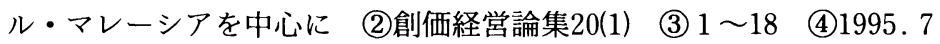

浦野起央, 田沢佳昭 (1)南海諸島をめぐる国際紛争史 2 (2)政経研究31(3)(日本大学) (3) $509 \sim 604$ (4) 1995.2

浦野起央, 田沢佳昭 (1)南海諸島をめぐる国際紛争史 3 (2)政経研究31(4)(日本大学) (3) $711 \sim 804 \quad$ (4) 1995.3

浦野起央, 田沢佳昭 (1)南海諸島における戦後国際紛争史 1 (2)政経研究31(2)（日本 大学法学会） (3)219〜302 (4) 1995.4

大石 周 (1)戦後アジア賠償問題と米国の対日占領政策(下) (2)大阪市大論集79 (3) 21〜66 (4)0995. 7

大呑善晃 (1)ハブと, イモ貝と, 虹と, 暁の象徵考古学(1)一一古代人はなぜ貝の飾り

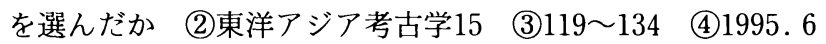

小川 博 (1)萬震「南州異物志」に記述された船 (2)日本海軍史の諸問題, 船舶編 (文 $\begin{array}{lll}\text { 献出版) (3) } 305 \sim 317 & \text { (4) } 1995.5\end{array}$

神尾真知子 (1)外国人労働者の社会的権利の保障—ASEAN 諸国間の労働力の移 動を中心に (2)地域協力機構と法——アジア・ラテンアメリカ地域主義の 現代的意義（アジア経済出版会）（3)69９9 $\quad$ (4)1994.12

加納啓良 (1)国際貿易からみた20世紀の東南アジア植民地経済 (2)歴史評論539 39〜55 (4) 1995.3 
加留 博 (1)官民協力による国際協力推進の一方策 一一本 ASEAN 投資基金の構 想と活動経験 (2)社会科学討究40(2)（早稲田大学） (3)253～275 (4) 1994.12

桐山 昇 (1)統合モデルとしての ASEAN ——帰属意識の複合性 (2)思想850 184〜199 (4)1995. 4

桐山 昇 (1)日本軍政期崩壊と東南アジア一一戦争責任・植民地再征服そして独立へ の国際秩序 [特集戦後世界形成の 50 年］（2)歴史学研究672 (3) 2 ～11 (4) 1995.6

KIMBARA, Tatsuo (1) Technology Transfer by Japanese Companies in ASEAN $\begin{array}{llll}\text { and Australia (2)経済論叢18(3)（広島大学） } & \text { (3)18～37 } & \text { (4) } 1994.11\end{array}$

GOTO, Ken-ichi (1) Japanese Colonialism in Southeast Asia (2) Historical Studies in Japan(VIII)1988 1992, ed. by The National Committee of Japanese Historians（山川出版社） (3)141 151 (4) 1995.8

小林昭三 (1)東・東南アジア的人権理解について (2)社会科学討究40(2) (早稲田大学) (3) $277 \sim 289$ (4) 1994.12

清水嘉治 (1)世界経済における三つの地域経済圈の性格と課題—NAFTA，EU， 東アジア経済会議 (EAEC) を中心にして (2)商経論叢30(2) (神奈川大学) (3) $97 \sim 176$ (4) 1994.11

清水嘉治 (1)東アジア研究の旅—タイ・シンガポールの日本工場を訪ねて (2)商経 論叢30(3)（神奈川大学）（3213～244 $\quad$ (4)1995.1

末廣 昭 (1)アジア工業化のダイナミズム (2)20世紀資本主義覇権の変容と福祉国家

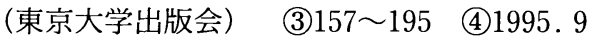

末廣 昭 (1)経済再進出への道——日本の対東南アジア政策と開発体制 (2)戦後日 本第 6 巻（岩波書店） (3)42 $\quad$ (4)1995.11

末廣 昭 (1)多国籍企業経済変動 (2)世界政治の構想変動 3 発展 (3)33〜86 (4) 1994.12

鈴木理恵子 (1)東南アジアの安全保障— ASEAN 地域フォーラムの課題 (2)海外 事情43(3) (3)17〜33 (4)1995. 3

関本照夫 (1)日本の人類学と歴史学 (2)講座日本通史・別巻 1 ：歴史意識の現在 (3) 123 147 (4) 1995.10

立本成文 (1)海域とネットワーク (2)講座・文明と環境10 一一海と文明（朝倉書店） (3)189 199 (4) 1995.10

田中恭子（1) ASEAN 諸国と中国建設的エンゲージメントへ（2)国際問題1995.1 No.418 (3) $17 \sim 29$ (4) 1995.1

田中耕司 (1)海域世界と稲作の伝播 (2)講座・文明と環境10 一一海と文明(朝倉書店) (3) $131 \sim 147$ (4) 1995.10

谷浦孝雄 （1)アジア NIES 論の再検討（2)アジア研究41(1) (3) 1 24 (4)1994.12 
玉置泰明 (1)開発と民族の未来一一開発人類学は可能か (2)民族誌の現在一一近 代・開発・他者（弘文堂） (3)88 106 1 (4) 1995.1

坪内良博 (1)19世紀中葉の東南アジアの人口 Journal of Indian Archiperago and Eastern Asiaにおける記述をめぐって (2)東南アジア研究32(3)（京都大 学) (3)225〜305 (4)1994.12

夏目文雄 (1)東南アジア刑法におけるコンスピラシー1 (2)愛知大学国際問題研究所 紀要102 (3)159〜179 (4)1995. 3

奈良修一 (1)鄭成功関係欧文目録 (2)鄭成功生誕370周年記念 (3)85９5 (4)1994.7

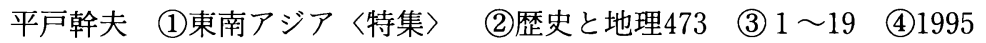
吹抜悠子（共同執筆） (1)〈史料〉李朝実録琉球国史料（訳註）六 (2)東南史学44 76〜99 (4) 1994.11

HOSHINO, Tatsuo (1) Reappraisal of the Chinese texts on Shi Li Fo Shi: Dvaravati and Sri Buddaha Sei(?) (2)東京外大東南アジア学 1 (3) $21 \sim 41 \quad$ (4) 1995.3

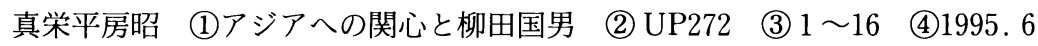
真栄平房昭 (1)沖縄歷史研究と安良城盛昭 (2)日本封建社会成立史論 (下) $280 \sim 298$ (4) 1995.6

真栄平房昭 (1)琉球ルートの海外情報 （2)月刊歷史手帖23(6) (3)17〜24 (4)1995. 6 $\begin{array}{lllll}\text { 真栄平房昭 (1)アジアへの関心と柳田国男 } & \text { (2) UP273 } & \text { (3)11〜15 } & \text { (4) } 1995.7\end{array}$ 村田 武 (1)東南アジアのコーヒー加工輸出業者—インドネシア・ベトナム・シン

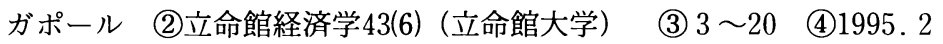

山田 均 (1)カンボジア仏教の復興とタイ仏教 (2)南方上座部仏教の展開と相互交流 に関する総合的研究（文部省科学研究費報告書） $\quad$ (3)33 45 (4) 1994.3

山本達郎 (1)歴史学の未来像 (2)日本学士院紀要49(3) (3)153〜165 (4)1995. 3

山本信人 (1)リム・ブーンケンによる「近代的中国人」の創造——進歩」の時代に おける初期南洋華人ナショナリズ研究試論 (2)法学研究68(5)（慶應義塾大 学) (3) $27 \sim 66 \quad$ (4) 1995.5

吉原和男 (1)華僑が帰る村 (2)アジア読本中国（河出書房新社） (3)342〜349 (4) 1995. 4

吉原和男 (1)中国人社会の同郷結合と社会ネットワーク (2)華僑華人(東方書店) 195〜218 (4) 1995.3

和田正彦 (1)東南アジアの日本企業の工業生産 (2)東南アジアの社会と文化（放送大 学教育振興会) (3) $9 \sim 22$ (4) 1995.3

\section{〈ブルネイ〉}

森 元繁 (1)ブルネイにおける中国系商店・社名にみる言語感覚（ブルネイ国の中国 系商人の好む店名・社名)

(2)東京外大東南アジア学 1 (3) $43 \sim 48$ 
東南アジア 一歴史と文化一 No.25, 1996

1995. 3

〈ビル マ〉

アウンサン・スー・チー (1)平和の文化と発展の文化 (2)世界606 (3)121１26 (4) 1995.3

伊藤利勝 (1) Thu-gyi and Sittan (2)愛大史学 4 (愛知大学) (3)149〜1676 (4) 1995. 3

伊野憲治 (1)ミャンマー民主化運動と少数民族問題 (2)思想850 (3)114～138 (4) 1995. 4

岩城高広 (1)コンバウン朝期のシッターンについて—ハンタワディ地方の事例研 究 (2)東南アジア一歴史と文化一24 (3)100〜125 (4)1995.6

OKUDAIRA, Ryuji (1) A Study on a Mythology of 'Kingship' Described in Manugye Dhammathat-Significant of Muddha 'Beiktheik' or the Supreama coronation Ceremony (2)東京外大東南アジア学 1 (3)65〜83 (4) 1995.3

奥平龍二 (1)ビルマ王権の正統性「ムッダー・ベイッティッ（即位式）をめぐって」 (2)南アジア東南アジアにおける宗教, 儀礼, 社会——正統」, ダルマの波 及・形成と変容 Monumenta Serindica26（東京外国語大学アジア・アフリ 力言語文化研究所） $\quad$ (3275 292 (4)1995.3

大田周二 (1)未知の国ミャンマーの素顔——この眼でみた発展への希望と苦悩の政 $\begin{array}{llll}\text { 治状況を粗彫する (2)日本及び日本人1618 } & \text { (3)118～124 } & \text { (4) } 1995.4\end{array}$

高橋昭雄 (1)上ビルマ農村の農外就業と階層構造——社会主義体制末期の一灌溉村 を事例として。(2)東南アジア農村の就業構造（アジア経済出版会） (3) $51 \sim 78$ (4) 1995.3

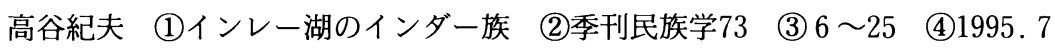
高谷紀夫 (1)ビルマ精霊伝説考—ーーミョウシン (Ko Myo Shin) の伝承から (2) Monumenta Serindica26（東京外国語大学アジア・アフリカ言語文化研究 所) (3) $293 \sim 310$ (4) 1995.3

土橋泰子 (1)小説に描かれたビルマの家族像—モゥ・モゥ（インャー）の場合 (2) 東京外大東南アジア学 1 (3)57〜64 (4)1995. 3

THAN TUN (1) GOLD TRACTS OF MEZA AND MU (2)東京外大東南アジア学 1 (3) $99 \sim 106 \quad$ (4) 1995.3

タン・トゥン（1)ビルマの仏足石（伊東照司訳編注） (2)東京外大東南アジア学 1 $123 \sim 134$ (4) 1995.3

中村 都 (1)ビルマ軍事政権（SLORC）の市場経済化政策—ASEANによる「建

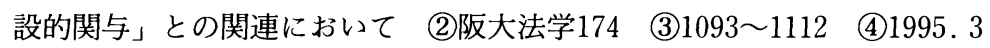
根本 敬 (1)植民地ナショナリストと総選挙——独立前ビルマの場合 $(1936$ ／1947) 
(2)アジア・アフリカ言語文化研究48／49(東京外国語大学) (3)81〜109 (4) 1995. 1

野村 亨 (1)ビルマの英語教育（2) SFC ジャーナル Vol.4（慶應義塾大学） (3) 5 $\sim 27$ (4) 1995.6

速水洋子 (1)カレン族における秩序と豊饒，男と女 (2)洗練と粗野(東京大学出版会)

(3) $153 \sim 168$ (4) 1995.3

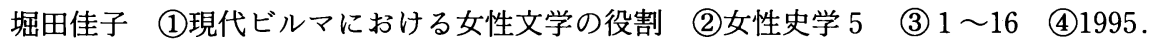
7

堀田佳子 (1)訳・解読マウン・ターヤの犬たち (2)世界文学81（大阪外国語大学） 169〜211 (4) 1995.3

南田みどり (1)現代ビルマにおける小説の可能性—ティンペーミンの達したもの (2)世界文学80（大阪外国語大学）

MI MI KYAW (1) Temple of Pagan Era (2)東京外大東南アジア学 1 (3)107〜122 (4) 1995.3

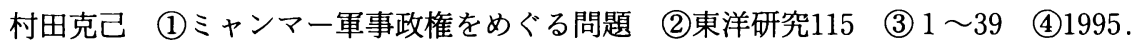
1

\section{〈カンボジア〉}

石澤良昭 （1)アジアの文化遺産と国際協力（2)文化遺産と環境(朝倉書店） (3) 1 12 (4) 1995.11

石澤良昭 (1)密林に花咲いたアンコール文明 (2)文化遺産と環境（朝倉書店） 14〜25 (4) 1995.11

伊東照司 (1)アンコール・ワットの建立神説について (2)南方文化21 (天理大学) 167〜182 (4) 1994.11

伊東照司 (1)アンコール・ワット第一回廊に見る大壁面「アニルッダ救済物語」 社会科学討究40(3) (早稲田大学) $\quad$ (3) $391 \sim 408$ (4) 1995.3

OHASHI, Hisatoshi (1) A Study of Cambodian Political Awareness (2)東京成徳 大学紀要 2 (3) $55 \sim 78$ (4)1995. 6

OHASHI, Hisatoshi (1) On a Social Awareness in Cambodia (2)淑德短期大学研 究論文集 1 (3)221 228 $\quad$ (4)1995.7

大橋久利 (1)非合法 2 年目, 孤立化深めるクメール・ルージュ (2)新真1995. 7, 8 36〜43 (4) 1995.8

小田部雄次 (1)「カンボジア・タイムズ」に見る自衛隊撤収後のカンボジア (2)静岡 精華短期大学紀要 3 (3)165〜184 $\quad$ (4)1995. 1

加藤一夫 (1)地域民族紛争と国連平和維持活動・カンボジア問題（1992～93年）を中

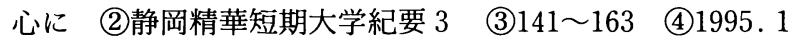

小橋史行 (1)カンボジア PKOにおける現実の一側面 (2)東亜329 (3)90〜100 
1994.11

福好昌治 (1)自衛隊はカンボジアPKOをいかに総括したか (2)東アジア研究 7 (大 阪経済法科大学）（3) $23 ３ 7$ (4) 1994.11

三上直光 (1)カンボジア語語彙資料——ポル・ポト時代から現在まで (2)言語・文化

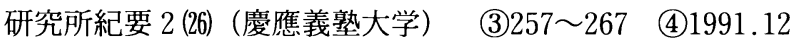

\section{〈インドネシア〉}

青山 亨 (1)アルジュナウィジャヤからスターソマへ (2)東洋學報77（1-2) $200 \sim 232$ (4) 1995.10

青山 亨 (1)叙事詩, 年代記, 予言：古代ジャワ文学にみられる伝統的歴史観 (2)東

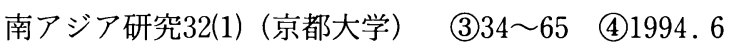

赤崎雄一 (1)20世紀前半ジャワの農民反乱と民衆意識 (2)史学研究209 (3)41 63 (4) 1995.8

AKASHI, Yoji (1) The East Timor Question in Australia — Indonesian Relations 1974 78: An Australian Perception (2) Working Papers Center For Australian Studies（南山大学） 5 (3) $1 \sim 49$ (4) 1995.3

AKIMICHI, Tomoya (1) Indigenous Resouce Management and Sustainable Developments: Case Studies from Papua New Guinea and Indonesia $\begin{array}{llll}\text { (2) Anthropological Science 103(4) } & \text { (3) } 321 \sim 327 & \text { (4) } 1995.10\end{array}$

伊賀正亮, 朝日幸代 (1)日本とインドネシアにおける公的投資と民間投資の計量経済 学的分析 (2)四日市大学論集 8 (1) (3) $1 \sim 42$ (4) 1995.9

ISHII, Kazuko (1) BOROBUDHUR, and the SARVATATHĀGATATATTVASAMGRAHA — A New Interpretation of Borobudhur (2)東京外大東 南アジア学 1 (3) $2 \sim 20$ (4) 1995.3

井上 真 (1)マカッサル人の山村における文化生態系の動態——インドネシア共和 国南スラウェシ州における治山プロジェクトの影響 (2)東南アジア研究33
(2) (京都大学)
(3) $224 \sim 244$
(4) 1995.9

大戸元長 (1)つわものどもは夢の跡（上）—ランポン民間農業協力 20 年後の検証 (2)海外農業開発212 (3) $1 \sim 11$ (4) 1995.8

大戸元長 (1)つわものどもは夢の跡 (下) — ランポン民間農業協力 20 年後の検証 (2)海外農業開発214 (3) $1 \sim 14$ (4) 1995.10

大橋厚子 (1)オランダ植民地支配と農作業層—1 1820 年代のプリアンガン地方の場 合 (2)東洋史研究53(3)（京都大学） (3)128～154 $\quad$ (4)1994.12

尾村敬二 (1)地方開発からみた持続成長の条件 (2)インドネシアにおける地方開発

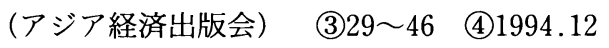

鏡味治也 (1)儀礼の正装論議に見る現代バリの宗教事情 (2)民族学研究60(1) (3) $32 \sim 52$ (4) 1995.6 
金谷尚知 (1)インドネシア国の農業, 農村開発協力 (2)開発学研究 5 (2) (3)99〜113 (4) 1995.3

木村敏明 (1)インドネシアとオランダ宗教現象学派の『未開宗教論』 (2)南方文化 21 (天理大学) (3) $39 \sim 69$ (4) 1994.11

倉沢愛子 (1)ジャワ農村実態調查解題 （2)ジャワ農村実態調查（龍溪書舎） （3) 1-11 (4) 1995.4

倉沢愛子 (1)日本軍占領下の米経済の変容 (2)南方共栄圏 一一 戦時日本の東南アジ ア経済支配（多賀出版）（3)645～672 (4)1995. 3

倉沢愛子 (1)インドネシア脱植民地化の過程にみるオランダと日本 (2)歴史学研究 672 (3)12〜24 (4) 1995.6

倉沢愛子 (1)インドネシアにおける日本軍政のもたらした影響 (2)東南アジア史の中 の近代日本（みすず書房） $\quad$ (3) $113 〜 131$ (4) 1995.7

後藤乾一 (1)戦後日本・インドネシア関係史研究序説 (2)社会科学討究40(2)（早稲田 大学) (3) $3 \sim 32$ (4) 1994.12

小松正昭 (1)金融自由化，内外資金移動，金融部門の課題 —インドネシアのケース

(2)発展途上国の金融改革と国際化（アジア経済出版会） (3) 3 ３4 (4) 1995. 2

左藤正範 (1)インドネシア語の辞書における「ロームシャ」について (2)京都産業大 学論集25(2) (3) $1 \sim 18$ (4) 1995.3

左藤正範 (1)インドネシア語の歷史教科書における「ロームシャ」について (2)東南 アジア研究32(4)（京都大学） (3)495〜522 (4)1995.3

佐藤百合 (1)インドネシアにおける経営近代化の先駆者—アストラグループの事 例研究 (2)アジア経済36(3) (3) 2 ～32 (4)1995. 3

SUKRISTIJONO, SUKARDJO (1) Soils in the Mangrove Forests of the Apar Nature Reserve, Tanah Grogotm Eats Kalimantan, Indonesia (2)東南 \begin{tabular}{ll|l} 
アジ研究32(3)（京都大学） & (3)385〜398 & (4)1994.12
\end{tabular}

ストポ・スタント (1)日本軍政とインドネシアの独立——神の試練としての前田海軍

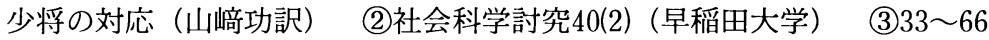
(4) 1994.12

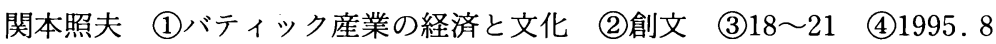

関本照夫 (1)ジャワにおける行為の美的規範と社会秩序 (2)洗練と粗野（東京大学出 版会）（3)76〜93 (4)1995.3

染谷臣道 (1)アルースとカサール—ージャワ社会の差異化と一体化 (2)洗練と粗野 (東京大学出版会) (3)56～75 (4) 1995.3

TAKAOKA, Yuki (1) The Process of Constructing and Tuning the Gong Ageng of Javanese Gamelan (2) Music cultures in interaction-cases between Asia and Europe Tokyo: ACADEMIA MUSIC Ltd. 
東南アジア 一歴史と文化一 №.25,1996

\section{$168 \sim 1777 \quad$ (4) 1994.12}

垂石征一，横田徹 (1)インドネシアの酪農——その小史と生産状況（調査レポート） (2)畜産情報（海外編） 70 (3) $46 〜 61 \quad$ (4) 1995.7

辻 雅男 (1)アグリビジネスの展開と農産物流通——ンドネシアの事例 (2)不完 全市場下のアジア農村（ア:ジア経済出版会）（3119１44 (4)1995

土屋健治 (1)インドネシアにおけるナショナリズムの現在 (2)ナショナリズムの現 在：戦後日本の政治(年報政治学1994, 岩波書店） (3)117～136 (4)1994.12 津守佳代子 (1)権威主義と経済成長——インドネシアのケース (2)アジア研究41(2) (3) $1 \sim 30$ (4) 1995.4

利光正文 (1)植民地期アチェのムハマディヤ運動（2)東南アジア・歴史と文化24 76〜99 (4) 1995.6

ドロジャトゥン・クンチョロヤクティ, ヌズル・アフヤル (1)インドネシア東部の開 発問題 (2)インドネシアにおける地方開発（アジア経済出版会） $105 \sim 134$ (4) 1994.12

長田 博 (1)インドネシアの貿易・外資自由化と総要素生産性 (2)貿易自由化と経済 発展一一途上国における生産性分析（アジア経済出版会）（3191～214 (4) 1995.1

奈良修一 1オランダ艦隊と中国人についての一考察 (2)東方10 (3) $268 ２ 78$ (4) 1994.12

西村重夫 (1)インドネシア (2)21世紀をめざす世界の教育 (3)64７8 (4) 1994.11 $\mathrm{M} ・$ ハティブ・バリス， $\mathrm{R} ・ \mathrm{M} ・$ マイケル・テネ (1)貧困対策とインプレスの役割 (2) インドネシアにおける地方開発（アジア経済出版会） (3) $91 〜 104$ (4) 1994.12

原 誠 (1)日本基督教団南方派遣——宣教師とインドネシアの教会 (2)基督教研 究56(1)（同志社大学） (3) $23 \sim 48$ (4) 1994.11

ハリリ・ハディ, ニニン・エ・スシロ (1)インドネシアにおける地域間開発協力

インドネシアにおける地方開発（アジア経済出版会） (3)69～90 1994.12

HIROSUE, Masashi (1) The development of National, Regional, and Interregional studies in Indonesia (2) Asian Research Trends. 1 No. 5 (3) 115〜134 (4) 1995.6

ファイサル・H・バスリ，モハマド・イッサン (1)インドネシア経済開発の実績 (2) インドネシアにおける地方開発（アジア経済出版会） (3) 3 ２8 (4) 1994.12

Roche, Frederic C. (1)インドネシアの灌溉稲作における化学肥料施用の技術的, 価 値的効率性 (2)国際農林業協力18(2) (3)17～33 $\quad$ (4)1995. 9

ヘラ・スサンティ, アリンドラ・A・ザイナル (1)地域開発の方向 (2)インドネシア 
における地方開発（アジア経済出版会） (3)47〜68 (4) 1994.12

エディ・ヘルマワン (1)インドネシア華商の対中投資について (2)東洋研究115

$33 \sim 54$ (4) 1995.1

増田与 (編訳) (1)スカルノ時代の終わりに (2)社会科学研究40(2) (早稲田大学)

$$
1 \sim 96 \text { (4) } 1994.12
$$

三木 誠 (1) Bungan一一央ボルネオにおける宗教改革運動 (2)南方文化21 (天理 大学) (3) $23 \sim 38$ (4) 1994.11

水野広祐 (1)インドネシア農村における多就業構造と農村雑業層——西ジャワ・プリ アンガン高地における農村工業村の事例 (2)東南アジア農村の就業構造

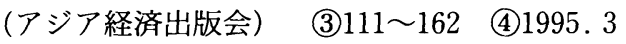

水野広祐 (1)インドネシア（日本における発展途上地域研究1986～94地域編東南アジ ア） (2)アジア経済36 ( $6 / 7$ ) (3) $84 〜 112$ (4) 1995.7

宮本謙介 (1)インドネシアにおける開発と労働問題 (2)アジア・アフリカ研究34(4) (3) $2 \sim 26$ (4) 1994.12

宮本謙介 (1)モノカルチュアへの道一一植民地ジャワ (2)講座世界史 4 ・資本主義は 人をどう変えてきたか（東京大学出版会） (3) $115 〜 136$ (4) 1995.9

村井吉敬 (1)東インドネシア諸島における伝統的資源保護慣行・サシについての覚え 書き (2)社会科学討究40(2) (早稲田大学) (3) 95 122 (4) 1994.12

MORIYAMA, Mikihiro (1) Language Policy in the Dutch Colony : on Sundanese in the Dutch East Indies (2)東南アジア研究32(4)(京都大学) (3)446〜454 (4) 1995.3

矢野敬生 (1)樫木網漁をめぐる諸慣行——東部ジャワ干潟漁村の事例 (2)社会科学 討究40(2) (早稲田大学) $\quad$ (3) $123 \sim 153$ (4) 1994.12

YAMAMOTO, Nobuto (1) Colonial Survveillance and "Public Opinion": The rise and Decline of Balai Poestaka's Press Monitoring” (2) Keio Journal of Politics8 (3) $71 \sim 100$ (4) 1995.10

山本信人 (1)秩序と安寧のために——新聞統制令からみた1930年代の蘭領インド (2)法学研究68 (10) (3) $143 \sim 170$ (4) 1995.10

山本信人 (1)メダンのロマン・ピチサン—1930年代末インドネシア文化地図と大衆 小説をめぐる政治 (2)法学研究68 (11) (3)147〜179 (4)1995.11

山本春樹 (1)バタック宗教とキリスト教——A.B. シナガのバタック宗教論をめぐっ て (2)南方文化21（天理大学） (3) $9 \sim 22$ (4) 1994.11

横山繁樹 (1)農業の多様化と小作制度変化——西ジャワ天水農業の事例から (2)不 完全市場下のアジア農村（アジア経済出版会） (3)87〜118 (4)1995. 3

吉田竹也 (1)表層の遊戯——バリ闘鶏に関するもう一つの解釈 (2)南方文化21(天理 大学) (3) $70 \sim 85$ (4) 1994.11

吉田竹也 (1)ムヌホロ—バリ島のヒンドウーの祈り (2)人類学研究所通信 $3 / 4$ 
東南アジア 一歴史と文化一 №.25, 1996
（南山大学）
(3) $2 \sim 12$
(4) 1995.4

米倉 等 (1)穀物流通の変化と農村金融市場——東ジャワの事例 (2)不完全市場下 のアジア農村（アジア経済出版会）（3145～186 (4)1995

\section{〈ラオ ス〉}

新田栄治 (1)石壹と百万頭の象の国——オスの古代文化 (2)福岡からアジアへ 2
(西日本新聞社)
(3) $150 \sim 177 \quad$ (4) 1995.2
新田栄治 (1)東南アジアの国家成立前夜 (2)展望考古学(考古学研究会) (3) $262 \sim 269$ (4) 1995.6

NITTA, Eiji (1) Prehistoric Industries and the Mekong Civilization (2)鹿児島大 学史学科報告 42 (3) $1 \sim 19$ (4) 1995.7

\section{〈マレーシア〉}

明石陽至 (1) Nanyo kyo kai 1915 1945 (2)社会科学討究40(2) (早稲田大学)

$$
1 \sim 29 \text { (4) } 1994.12
$$

アブドゥル・アジズ (1)プロトン社下請計画によるブミプトラ中小企業の育成——ト ラコーマ社の事例研究 (2)ブミプトラ企業の抬頭とマレー人, 華人経済協 力（アジア経済出版会） (3) $37 〜 62$ (4) 1995.3

石井由香 (1)日本の華人系マレーシア人非合法滞在者一一面接調査を通じて (2)南 方文化21（天理大学） (3) $123 \sim 151$ (4)1994.11

上杉富之 (1) Bridewealth/Food Exchange and Social Networks among the Murut of Sabah, East Malaysia (2) Man and Culture in Oceania 11 (日本才セ アニア学会）（323〜43 (4)1995

岡本由美子 (1)マレーシアの貿易・外資自由化政策と経済開発 (2)貿易自由化と経済 発展一一途上国における生産性分析（アジア経済出版会）（3)161～190 (4) 1995.1

OKUMURA, Misa (1)"Under Cross and Crescent —Catholics in Malaysia” . (2) The Journal of Sophia Asian Studies 12 (上智大学) (3) $157 \sim 172$ (4) 1994.12

アイリーン・シア (1)楊一族一市場を求めて (2)ブミプトラ企業の抬頭とマレー人, 華人経済協力（アジア経済出版会）（3)123１48 (4) 1995.3

島村 力 (1)マハティール首相の持論 (2)海外事情42(11)（拓殖大学） (3) $86 〜 101$ (4) 1994.11

清水 洋 (1)戦前期日本の対英領マラヤ貿易拡張——神戸華商の役割を中心として (2)愛知淑徳大学論集20 $\quad$ (3) $85 \sim 96$ (4) 1995.3

Umer JUNUS (1)“Kaba: An Unfinished (His-) Story” (2)東南アジア研究32(3) (3) $399 \sim 415$ (4) 1994.12 
白坂 蕃 (1)マレーシアに関する地域研究ノート (2)東京学芸大学紀要 [社会]46 (3) $153 \sim 175$ (4) 1995

竹熊尚夫 (1)多民族社会マレーシアにおける民族教育研究に関する考察 (2)比較教育

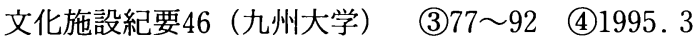

トウ・キンウーン (1)台湾のマレーシア投資——ミクロ・マクロ分析 (2)ブミプトラ 企業の抬頭とマレー人，華人経済協力（アジア経済出版会）（3)149～174 (4) 1995.3

永田淳嗣 (1)ジョホール・マラッカ海峡沿岸におけるある在地権力者の農園経営 (2)

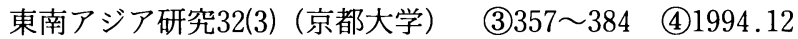

根津 敦 (1)言語と民族アイデンティティー問題の政治化一一州原住民 (2) SFC Journal of Language and Communication 4（慶應義塾大学）（3)74～89 (4) 1995.3

原不二夫 (1)中国の対マレーシア投資 （2)ブミプトラ企業抬頭とマレー人，華人経済 協力（アジア経済出版会）（3175～222 (4)1995. 3

パン・テクワイ (1)サバ財団の設立と変革——サバ州最大の単独社会, 経済事業グル ープ (2)ブミプトラ企業の抬頭とマレー人，華人経済協力（アジア経斉出 版会）（3) $63 〜 100$ (4) 1995.3

藤巻正己 (1)都市スクォッターの政治社会論——半島マレーシアの「対立の構図」と の脈絡において (2)南方文化21（天理大学） (3)103〜122 (4)1994.11

藤本彰三 (1)マレーシア農民の就業変化の構造と方向——稲作農村の考察を中心と して (2)東南アジア農村の就業構造(アジア経済出版会) (3)211〜238 (4) 1995. 3

マンソール・モハメド・イサ (1)ブミプトラによる新興事業——モファス・グループ (2)ブミプトラ企業の抬頭とマレー人，華人経斉協力（アジア経済出版会）

(3) $7 \sim 36$ (4) 1995.3

水島 司 (1)プランテーション世界とタミル民族 (2)叢書カースト制度と被差別民 4

(3) $451 \sim 495$ (4) 1995.1

水島 司 (1)“A Historical Study on Land Transaction in a Perak Kampong” Human Ecology in Rural Malaysia（駒沢大学） (3) $17 〜 54$ (4)1995. 4 宗像 朗 (1)ミクロレベルの村落開発プロジェクトがもたらす社会的影響——青年 海外協力隊「マレーシア・サバ州村落開発プロジェクト」の事例から 援助の社会的影響（アジア経済出版会） $\quad$ (3) $37 〜 63$ (4) 1994.10

吉村真子 (1)マレーシアの工業化と労働力構造——日系企業A社のケース (2)社会 労働研究41（1,2）（法政大学） $\quad$ (3) $171 \sim 184$ (4) 1994.9

吉村真子 (1)マレーシアの日系企業と地域社会——スランゴール州のマレー・カンポ ンのケースから (2)地域学研究 8 (3) $115 \sim 143$ (4) 1995.3

吉村真子 (1)マレーシアの新経済政策（1971～90年）と就業構造 (1) (2)社会労働研 
究42(1)（法政大学） (3) $131 〜 146$ (4) 1995.6

吉村真子 (1)マレーシアの経済発展と労働力構造—— 新経済政策下の就業構造の変

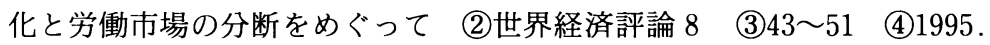
8

吉村真子 (1)マレーシアの新経済政策（1971～90年）と就業構造 (2) (2)社会労働研 究42(2) (法政大学) (3) $92 \sim 139$ (4) 1995.9

ルガヤ・モハメド（1)華人—ーブミプトラ間の事業協力 (2)ブミプトラ企業の抬頭と

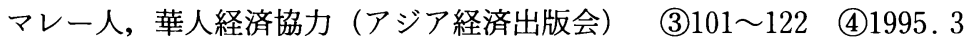

\section{〈フィリピン〉}

梅原弘光 (1)フィリピン農村の就業構造——部ルソンの一米作農村における事例 (2)東南アジア農村の就業構造（アジア経済出版会） (3)79１10 (4)1995. 3

太田和宏 (1)フィリピン農地改革の新形態——ルイシタ農園における株式分配方式 の実態 (2)アジア経済36(10) (3)42〜65 (4)1995.10

小原篤次 (1) Aid Administration in Political Transaction Period: Turnover from NEDA after Marcos Administration（2)国際開発学会文集1995 (3)118～ 121 (4) 1995.11

梶原弘和 (1)フィリピンの貿易・外資自由化政策と生産性変化 (2)貿易自由化と経済 発展——途上国における生産性分析（アジア経済出版会） (3) $215 ２ 40$ (4) 1995.1

川中 豪 (1)ラモス政権下の行政改革——開発の土台形成に向けた試み (2)アジア

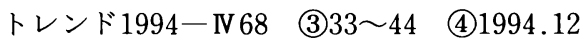

坂井秀吉 (1)フィリピンの銀行制度——過去の経験と教訓 (2)フィリピンの国内資 源動員とその利用（アジア経済出版会）（3101～150 (4)1995. 3

佐竹真明 (1)フィリピンの家内中小工業政策 ——歴史・現状・問題点・展望 (2)アジ ア研究41(2) (3) $31 \sim 63$ (4) 1995.4

菅谷成子 (1)十八世紀中葉フィリピンにおける中国人移民社会の変容と中国系メステ ィーソの興隆——対英協力中国人の追放をめぐって (2)東洋学報76（3， $\begin{array}{lll}\text { 4) (6) } 61 \sim 91 & \text { (4) } 1995.3\end{array}$

菅谷成子 (1)フィリピンとメキシコ (2)歴史学研究会編講座世界史 1 ・世界史とは何 か（東大出版会） $\quad$ (3) $203 \sim 228$ (4) 1995.5

杉井 信 (1)葬送儀礼と即興歌——フィリピン山地民ティンギャンの儀礼変化 (2) 社会人類学年報 21 (3) $115 \sim 126$ (4) 1995.10

杉井 信 (1)ティンギャンの平和協定単位——フィリピン山地民社会におけるく共同 $\begin{array}{llll}\text { 体〉再考 (2)民族学研究59-3 } & \text { (3) } 221 \sim 243 & \text { (4) } 1994.12\end{array}$

角田宇子 (1)小規模灌溉プロジェクトと社会文化的要因——フィリピンの事例から 
(2)援助の社会的影響（アジア経済出版会）（3)165２01 (4)1994.10 関 一敏 (1)われわれのようでないものたち——フィリピン・ビサヤ地方シキホール

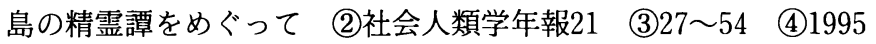

滝川 勉 11フィリピンの農林漁業開発と環境問題——自然と人間の共生と農林漁 業の視点 (2)開発学研究 5(2) (3) $6 \sim 13$ (4) 1995.3

玉置泰明 (1)フィリピン初期キリスト教化をめぐる覚書——ラファエルの「翻訳」改

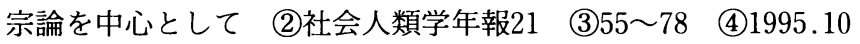

エマニエル・S・ディオス (1)資源動員と産業組織 (2)フィリピンの国内資源動員とそ の利用（アジア経済出版会） $\quad$ (3) $67 〜 100$ (4) 1995.3

ベンジャミン・E・ディクノ（1)フィリピンにおける租税と民間部門資源の動員 (2)フ ィリピンの国内資源動員とその利用(アジア経済出版会) (3)177〜198 (4) 1995. 3

寺見元恵 (1)日本占領下フィリピンにおける文化工作—— 新比島教育隊の例 (2)ア ジアの文化と社会（法律文化社） $\quad$ (3) $245 ２ 75$ (4) 1995.6

中西 徹 (1)フィリピンにおける都市インフォーマル部門の変容：1985～94 (2)経済 学論集61(1) (3) $42 \sim 63$ (4) 1995.4

永野善子 (1)フィリピン砂糖キビ作地帯の協同組合経営——地主主導型土地移転と 農園労働者の自立過程 (2)アジア経済36(10) (3) 2 27 (4) 1995.10

萩野芳夫 (1)フィリピンの人種保障序論 (2)社会科学研究15(1)(中京大学) (3) $41 \sim 58$ (4) 1995.1

カイエ夕ノ・W・パデランガ (1)フィリピンにおける投資計画の理論と実際 (2)フィ リピンの国内資源動員とその利用（アジア経済出版会）（3)199～246 (4) 1995. 3

早瀬晋三 (1)フィリピン行き渡航者調查 (昭和期) (2)人文研究 (大阪市立大学) $671 \sim 696$ (4) 1994.12

ラウル・V・ファベリア (1)マクロ経済安定下での投資および資源配分 (2)フィリピン の国内資源動員とその利用（アジア経済出版会） （3)151～176 (4) 1995.3

深澤安博 (1)フィリピンのスペイン共和国派（上） (2)歴史評論542 (3)79９2 (4) 1995. 6

深澤安博（1)フィリピンのスペイン共和国派（下）（2)歴史評論543 (3)79～89 1995. 7

ホノリナ・B・タンフェコ (1)フィリピンにおける貯蓄と投資の決定要因 (2)フィリピ ンの国内資源動員とその利用（アジア経済出版会） $\quad$ (3) $43 〜 66$ (4) 1995.3

室屋有宏（1)フィリピンにおける輸出農業の形成（2)経済学56(4) (3)167～179 (4) 1995

森沢恵子 (1)現代フィリピン経済の分析枠組み試論-1- (2)季刊経済研究17(3) $24 \sim 40$ (4) 1994.12 
山本康隆 (1)フィリピンの実情と将来への展望に関する一考察 (2)関西外国語大学研 究論集61 (3)61 635 (4)1995. 1

ジョセフ・Y・リム（1)フィリピンの余唾蓄積動向に関するマクロスタディー1970～92

(2)（アジア経済出版会） $\quad$ (3) $3 〜 42$ (4) 1995.3

\section{〈シンガポール〉}

佐藤孝一 (1)シンガポールのマレー人政策——゙ループ代表選挙区制導入の一背景 (2)アジア研究41(1) (3)25〜58 $\quad$ (4) 1994.12

田中恭子 (1)シンガポール社会の多言語状況—1980年代における変化の検証 アジア経済35(12) (3)26〜36 $\quad$ (4)1994.12

CHANG Han Yin (1)"Singapore: Education and Change of Class Stratification" (2)東南アジア研究32(4) (京都大学) (3)455〜476 (4) 1995.3

CHENG Lim Keek (1)"Patterns of Social Alignment: A Case Study of Hakka Associations in Singapore” (2)東南アジア研究32(49)（京都大学) 477〜496 (4) 1995.3

根布厚子 (1)セアンスにおける災因論を通してみた霊媒の性格——シンガポールの

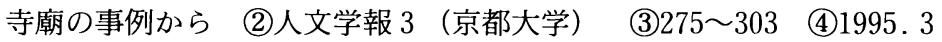

根布厚子 (1)エスニシティとマンダリン—ーシンガポールにおける中国系住民の場 合 (2)比較文学・文化論集（東京大学） $\quad$ (3) $114 〜 126$ (4) 1995.3

根布厚子 (1)シンガポール中国寺廟の問神——依頼者と依頼内容をめぐって (2)東 南アジア歴史と文化24 (3)49〜75 $\quad$ (4)1995. 6

WARREN, James Francis (1)"A Strong Stomach and Flamed material : Towards the making of a Trilogy, Singapore, 1870 1940" (2)東南アジア研究33 $\begin{array}{lll}\text { (2) (京都大学) } & \text { (3) } 245 \sim 264 & \text { (4) } 1995.9\end{array}$

〈タ 1 〉

阿部和俊 (1)夕イの人口の地域構造 (2)研究報告 [社会］44（愛知教育大学） (3) 1 $\sim 18$ (4) 1995

新谷正彦 (1)夕イの経済発展と資本浅化 (2)東洋文化研究所紀要127 (東京大学) $43 \sim 68$ (4) 1995.3

池本幸生 (1)夕イ家電産業の発展と市場構造 (2)産業発展と産業組織の変化（アジア 経済研究所） (3) $323 \sim 360$ (4)1995. 5

池本幸生 (1)夕イの自動車組立産業と自由化政策 (2)産業発展と産業組織の変化（ア

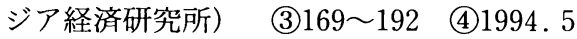

石井米雄 (1)スコータイ・アユタヤ（試論）——第十一刻文の検討を中心に (2)東方 学89 $\begin{array}{lll}\text { (3) } 1 \sim 16 & \text { (4) } 1995.1\end{array}$

泉 経武 (1)夕イ村落社会における仏教の一動向——東北夕イの二人の開発僧をめ 
ぐって (2)言語・地域文化研究 1 (3)91〜104 (4)1995.3

市川拓也 (1)夕イの小売業界——急激に進展する業態変化 (2)アジア月報50 20〜30 (4) 1995.5

今永清二 (1)チャオプラヤ川流域のタイ・ムスリム社会の研究 (2)学術月報48(5) 31 37 (4) 1995.5

浦田秀次郎, 横田一彦 (1)夕イにおける貿易自由化と生産性への影響 (2)貿易自由化 と経済発展——途上国における生産分析（アジア経済出版会） 135〜160 (4) 1995.1

大野昭彦 (1)社会統制としての国家・社会そして対人関係——イと日本人大学生の 意識の比較からの試み (2)経済学雑誌 95 （5/16）

尾中文哉 (1)チットニプーサミックの「アユタヤ時代以前のチャオプラヤ川流域にお ける夕イ社会」（2)茨城大学人文学部紀要 (社会科学) 28 (3)115 129 (4) 1995. 3

北村かよ子 (1)夕イの教育開発の実態と問題点——基礎教育を中心に (2)開発と社 会（アジア経済出版会）（3111～121 (4)1995. 2

KONO, Yasuyuki, SAHA, Pradip Kumar (1) Land and Water Resources Management for Crop Diversification in the Chao Phraya Delta, Thailand:A Casestudy of Citrus Cultivation in the North Rangsit Irrigation Project (2)東南アジア研究33(2)（京都大学） (3)169〜186 (4)1995.9

坂本比奈子 (1)夕イ諸語の文法的比較研究 1 - ラオス・東北夕イ・北夕イを結ぶ夕 ム文字 (2)麗沢大学紀要59

重富真一 (1)参加型農村開発の組織論——東北夕イ農村に扔ける住民組織の形成過 程（2)アジア経済36(2) (3) $2 〜 24$ (4)1995.2

重富真一 (1)東北夕イにおける協同耕作の形成原理 (2)東南アジア研究33(2)（京都大 学) (3) $204 \sim 223$ (4) 1995.9

重富真一, 東茂樹 (1)夕イ一日本における発展途上地域研究1986 94地域編・東南 アジア (2)アジア経済36 $(6,7)$ (3)150〜163 (4)1995.7

SIRIKUNCHOAT SUMET (1)夕イ源泉徵収所得税の概念 (2)法学政治学論究24 (3) $451 \sim 496$ (4) 1995.3

末廣 昭 (1)チナワット・グループ—タイの情報通信産業と新興財閥 (2)アジア経 済36(2) (3)25〜60 (4)1995.2

末廣 昭 (1)夕イにおける拡大首都圈と地方経済圈 (2)総合的地域研究 9 (3) $3 \sim 9$ (4) 1995.6

関 泰子 (1)進行する兼業化とラムヤイ農業——変容する北部夕イ農村社会 (2)ア ジア研究41(2) (3)65〜106 $\quad$ (4) 1995.4

高嶋宏臣 (1)夕イの近況・高級化を目指す繊維産業 (2)化瀻月報569 (3)32〜50 (4) 1995. 9 
田坂敏雄 (1)バンコク・オフショア市場と金融の国際化 (2)立命館経済学43(6)（立命

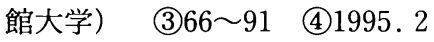

田坂敏雄 (1)夕イの外国為替相場制度と外為市場 (2)季刊経済研究17(4)（大阪市立大 学) (3) $1 \sim 17$ (4) 1995.3

田坂敏雄 (1)夕イの為替管理自由化と短期資本移動 (2)季刊経済研究18(1)（大阪市立 大学) (3) $1 \sim 31$ (4) 1995.6

CHANTACHOTE, VIRAVAT (1)タイにおけるファクタリングの生成と発展 (2) 法学政治学論究24 (3)215 257 (4)1995. 3

中田義昭 (1)余劋米と出稼ぎ—タイ東北部ヤソートーン県の 1 村を対象として (2)東南アジア研究32(4)（京都大学） (3) $523 〜 548$ (4) 1995.3

橋本 卓 (1)バンコクの都市化と郊外地域の変容 (2)夕イ：工業化と地域社会の変動 （法律文化社） (3)315〜363 (4)1995.2

橋本 卓 (1)工業化と都市化の変容 (2)夕イの工業化と社会の変容 (九州大学出版会) (3) $79 \sim 103$ (4) 1995.7

長谷川清 (1)宗教としての上座仏教—シシプソーンパンナー, タイ・ルー族の仏教 復興運動とエスニシティ (2)宗教・伝統・民族——デオロギー的考察 (南 山大学人類学研究所） (355 82 (4) 1995.3

馬場雄司 (1)北タイ, タイ・ルー族の守護霊儀式とその社会的背景——移住の記憶を たどって (2)宗教・民族・伝統——イデオロギー的考察（南山大学人類学 研究所) (3)83〜115 (4) 1995.3

馬場雄司 (1)農村をとりまく環境変化と民間信仰一一北夕イ,ナーン県の事例 (2)同 朋福祉 1 (3) $35 \sim 54$ (4) 1995.9

原洋之介 (1)アジアの奇跡の中のアジア農業———発展史と今後の課題 “夕イ” (2)国際農林業協力18(1) (3)16〜28 (4)1995.6

平井京之介 (1)家を化粧する一一北部夕イの女性工場労働者と消費 (2)民族学研究 59 (4) (3) $366 \sim 387 \quad$ (4) 1995.3

平田利文 (1)夕イ王国 (2)アジア諸国の社会·教育・生活と文化（エムティ出版） $111 \sim 124$ (4) 1994.3

平田利文 (1)夕イ——教育内容 (2)学校と地域社会との連携に関する国際比較研 究・中間資料集 1 （国立教育研究所） $\quad$ (3)432 437 (4) 1995.3

増井好男 (1)夕イ国におけるエビ養殖の発展と地域経済 (2)農村研究80 (3)28〜38 (4) 1995.3

増田えりか (1)ラーマ1世の対清外交 (2)東南アジア: 歴史と文化24 (3)25４5 (4) 1995.6

丸岡洋司 (1)夕イ社会圏における社会論理への接近と諸問題 (2)国際経営論集 9 （神 奈川大学）（357〜84 (4)1995.8

Shuichi Miyagawa (1) Expansion of an Imporoved Variety into Rain-Fed Rice 
Cultivation in Northeast Thailand (2)東南アジア研究33(2) (京都大学) (3) $187 \sim 203$ (4) 1995.9

森部 一 1 1)タイの僧院についての考察——仏陀の遺骨・仏塔崇拝 “ならびに”僧 院の経済的問題”との関連において (2)南方文化21 (天理大学) (3)49〜69 (4) 1994.11

吉岡みね子 (1)夕イ文学と政治——思想とテーマの変遷（1929～現在） (2)世界文学 80 (大阪外国語大学) (3) $57 〜 67 \quad$ (4) 1994.12

吉岡みね子 (1)夕イ文学と政治——命者たち (その1) シーブーラパーの帰国 (2) 世界文学81（大阪外国語大学） $\quad$ (3) $58 \sim 66$ (4) 1995.7

YOSHINO, Akira (1) Father and Son, Master and Diciples: The Patrilineal Ideology of the Mien of Northern Thailand (2) Perspectives on Chinese Society: Anthropological Views from Japan（東京外国語大学アジア・ アフリカ言語文化研究所） (3)265〜273 (4)1995

吉野 晃 (1)民族間関係と民族アイデンティティ——エン族の他民族養取 (2)民 族誌の現在 一一近代・開発・他者（弘文堂） $\quad$ (3) $53 \sim 69$ (4) 1995.3

\section{〈べトナム〉}

板野征神 (1)ベトナム瀻維産業とベトナムの暮らしについて (2)日本紡績月報573 (3) $16 \sim 27 \quad$ (4) 1994.11

今井昭夫 (1)20世紀初のベトナム愛国啓蒙運動における「国民」の創出——『国民読 本』などのドンナン義塾の塾書を中心に (2)東京外大東南アジア学 1 (3) 84〜98 (4) 1995.3

岩月純一 (1)「ベトナム語意識」の形成と「漢字／漢文」——『南風雑誌』に見る 東南アジア歴史と文化24 (3) 3 24 (4) 1995.6

岩見元子 (1)ベトナムの社会労働事情(特集労働問題1994〜95／海外の動向——体制

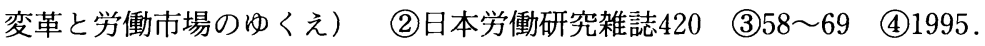
2

岩見元子 （1)躍進するべトナムとその投資環境調査季報 （2)国民32 (3)53〜69 (4) 1995

大出知敬 (1)ベトナムの近況 (2)経済調查563（大和銀行調査部） (3) 3 26 1995. 3

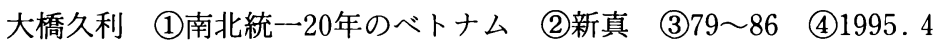

加藤泰彦 (1)八ノイでみた技術協力の最前線［特集ベトナムとヴェトナム人］（2)地 理40(6) (3)48〜56 (4) 1995.6

木之内秀彦 (1)中越ソ『友好』の断面—1950年のベトナムをめぐって (2)東南アジ ア研究32(3)（京都大学） (3)306〜356 (4)1994.12

栗原浩英 (1)戦後史の中のベトナム独立, 戦争 (2)歴史地理教育532 (3)82〜87 
1995. 4

栗原浩英 (1)べトナムにおける社会主義の歴史的経験 (2)歴史評論540 (3) 93 ～102 (4) 1995.4

栗原浩英 (1)コミンテルンのベトナム人活動家—1930年インドシナ共産党内の対

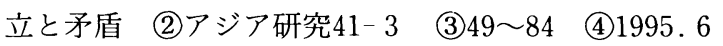

KONO, Yasuyuki, DOAN Doan Tuan (1) Effect of Water Control on Rice Cultivation in the Red River Delat, Vietnam: A Case Study in the Nhue River Irrigation System (2)東南アジア研究32(4) (京都大学) (3) $425 〜 445$ (4) 1995. 3

五島文雄 (1)ドイモイ下における国会の変容 (2)社会主義べトナムとドイモイ（アジ ア経済研究所） $\quad$ (3) $3 \sim 36$ (4) 1994.12

小林正樹, 中島緑子 (1)べトナム——豊かな可能性と今後の課題 (2)財界観測59(11) (3) $80 \sim 111$ (4) 1994.11

桜井由躬雄（1)ベトナム紅河デルタ（2)百穀社通信（3) 1 125 (4)1995. 1 桜井由躬雄 (1)辺境と集団性——紅河デルタ村落報告 (2)総合的地域研究 8 $10 \sim 18$ (4) 1995.3

桜井由躬雄, 大西和彦 (1)ベトナムの仏教——徐道行と仏跡山天福寺を中心として (2)東アジア仏教とは何か（春秋社） $\quad$ (3) $227 〜 244$ (4) 1995.4

桜井由躬雄 (1)ベトナム紅河デルタ村落研究報告——東南アジア地域辺境としての 人口密地帯 (2)百穀社通信 1 (3) $1 \sim 25$ (4) 1995.6

嶋尾 稔 (1)ベトナム阮朝期の挙人の出身地について (中) (2)言語文化研究所紀要 26 (慶應義塾大学) $\quad$ (3) $269 \sim 291$ (4) 1994.12

白石昌也 (1)ベトナムの東南アジア地域認識1975～1986年 (2)東洋文化研究所紀要 126 (東京大学) (3) $159 \sim 217$ (4) 1995.1

末成道男 (1)ベトナムの『家譜』 (2)東洋文化研究所紀要127 (東京大学) (3) $1 \sim 42$ (4) 1995.3

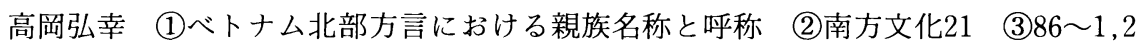
(4) 1994.11

TAKADA, Yoko (1) Rice and Colonial Rule; A Study on Tariff Policy of French Indochina (2) Institute of Enviromental Colonial Studies 3 (千葉敬愛 短期大学) (3) $21 \sim 36$ (4) 1995.4

田中孝彦 (1)インドシナ介入をめぐる米英政策対立——冷戦政策の比較研究試論 $\begin{array}{llll}\text { (2)一橋論叢114(1)（一橋大学） } & \text { (3) } 59 \sim 79 & \text { (4) } 1995.7\end{array}$

丹野 勲 (1)ベトナムの企業経営——゙イモイ政策・外資政策・日本企業の進出を中 心として (2)国際経営論集 8 (神奈川大学) (3) $81 〜 113$ (4)1995. 2

丹野 勲 (1)ベトナムの経済・経営の背景 (2)国際フォーラム6 (神奈川大学) $55 \sim 68$ (4) 1995.3 
坪井善明 (1)解放20周年のヴェトナム $\quad$ (2)世界609（岩波書店） (3)170～176 (4) 1995. 5

中田友子 (1)ヴェトナム中部高原少数民族における交易に関する覚書き (2)歴史と構 造23（南山大学） $\quad$ (3) $3 \sim 16$ (4) 1995.3

奈良修一 (1)トンキンに関するオランダ東インド会社史料 (2)南方文化21 (天理大学)

(3) $183 \sim 198$ (4) 1994.12

春山成子 (1)ソンコイ川下流デルタの地形環境 (2)国際関係学研究21 (3) $1 \sim 13$ (4) 1995. 3

春山成子（1)ベトナムの自然と資源[特集ベトナムとヴェトナム人］（2)地理40(6) $57 \sim 67 \quad$ (4) 1995.6

松尾信之 (1)べトナムの国立第一文書保管センター (2)ミュージアム九州50 (3) 32〜40 (4) 1995.6

松田晋哉 (1)べトナムにおける労㗢安全衛生の現状 (2)労働科学71(2) (3)49〜62 (4) 1995

宮本勝浩（1)ベトナム経済の現状と展望（2)経済研究40(3)(大阪府立大学) (3)29〜53 (4) 1995.5

村野 勉 (1)ベトナム——本における発展途上地域研究1986 94・地域編・東南ア ジア (2)アジア経済36 (6/7) (3)113〜123 (4)1995.7

桃木至朗 (1)広南阮氏と「ベトナム」国家 (2)南シナ海世界におけるホイアン (ベト ナム）の歴史生態的位置 I （文部省科学研究費報告書） (3)29～53 (4) 1995. 9

八尾隆生 (1)黎朝聖宗期の新開拓地を巡る中央政権と地方行政——安興碑文の分析 $\begin{array}{lll}\text { (2)東南アジア研究33(2)（京都大学） } & \text { (3)143〜168 } & \text { (4)1995. } 9\end{array}$ レー・バン・クー (1)複文における話し手の意図表現——べトナム語の “móri”（やっ と）の場合（2)東京外大東南アジア学 1 (3) $43 \sim 48$ (4) 1995.3

和田正彦 (1)漂流民の眼からみた十八世紀後半のヴェトナム (2)南島史学45 (3) 23〜41 (4) 1995.5

渡辺慎一 (1)ベトナムにおける金融システムの改革と海外要因 (2)発展途上国の金融 $\begin{array}{lll}\text { 改革と国際化（アジア経済出版会） } & \text { (3)35〜70 } & \text { (4)1995.2 }\end{array}$

\section{〈雲南・広西〉}

鈴木正宗 (1)銅鼓の儀礼と世界観についての一考察 (2)史学64 $(3,4)$ (慶應義塾大学) (3) $13 \sim 31$ (4) 1995.4

兽士才 (1) Christianity in Southwestern China: Mass Convension among the Miao and Yi. (2) Perspectives on Chinese Society: Views from Japan （東京外国語大学アジア・アフリカ言語文化研究所） (3)243〜258 1995. 3 
東南アジア 一歴史と文化一 №.25, 1996

宋 建華 (1)ダイ族の宗教教育について——国雲南省西双版納の現地調査報告 (2)比較文化研究施設報告紀要46（九州大学） 